\title{
BAP1 Loss of Function Mutation Positive
}

National Cancer Institute

\section{Source}

National Cancer Institute. BAP1 Loss of Function Mutation Positive. NCI Thesaurus. Code C150449.

An indication that expression of BAP1 with a loss of function mutation has been detected in a sample. 